\title{
Taxonomy of the Clostridia: Ribosomal Ribonucleic Acid Homologies among the Species
}

\author{
By J. L. JOHNSON AND BARBARA S. FRANCIS \\ Anaerobe Laboratory, Virginia Polytechnic Institute and State University, \\ Blacksburg, Virginia 24061, U.S.A.
}

(Received 21 August 1974; revised 29 November 1974)

SUMMARY

rRNA homologies have been determined on reference strains representing 56 species of Clostridium. Competition experiments using tritium-labelled $23 \mathrm{~S}$ rRNA were employed. The majority of the species had DNA with 27 to $28 \%$ guanine plus cytosine $(\% \mathrm{GC})$. These fell into rRNA homology groups I and II, which were well defined, and a third group which consisted of species which did not belong in groups I and II. Species whose DNA was $4 \mathrm{I}$ to $45 \%$ GC comprised a fourth group. Thirty species were placed into rRNA homology group I on the basis of having $50 \%$ or greater homology with Clostridium butyricum, C. perfringens, $C$. carnis, $C$. sporogenes, $C$. novyi or $C$. pasteurianum. Ten subgroups were delineated in homology group I. Species in each subgroup either had high homology with a particular reference species or a similar pattern of homologies to all of the reference organisms. The eleven species in rRNA homology group II had $69 \%$ or greater homology to $C$. lituseburense. Species in groups I and II had intergroup homologies of 20 to $40 \%$. The six species in group III had very low homologies with groups I and II. Negligible homology also resulted when five of the species were tested against the sixth, $C$. ramosum. The five species having DNA with $4 \mathrm{I}$ to $45 \% \mathrm{GC}$ were $C$. innocuum, $C$. sphenoides, $C$. indolis, $C$. barkeri and $C$. oroticum. Little rRNA homology was apparent between $C$. innocuum and the other high $\%$ GC species or with several Bacillus species having similar \% GC DNA. Correlations between homology results and phenotypic characteristics are discussed.

\section{INTRODUCTION}

rRNA cistrons are conserved to a greater extent than other cistrons in all groups of organisms examined (Bicknell \& Douglas, 1970; Doi \& Igarashi, 1965; Dubnau, Smith, Morell \& Marmur, 1965; Johnson, Anderson \& Ordal, 1970; Laird \& McCarthy, 1968; Moore \& McCarthy, I967; Pace \& Campbell, ı 97 I $a, b$; Takahashi, Saito \& Ikeda, I967; Vodkin \& Katterman, 197I; Gibson, 1967). Similarities in the nucleotide sequences of rRNA preparations have been reported between organisms that would normally be considered distantly related (Bendich \& McCarthy, 1970; Pigott \& Carr, 1972; Vodkin \& Katterman, 197I) and among representatives of diverse bacterial groups (Johnson et al 1970; Moore \& McCarthy, 1967; Pace \& Campbell, 197I b).

The organisms in the genus Clostridium are defined as being anaerobic, spore-forming and rod-shaped. Probably all of them have Gram-positive-type cell walls, although some appear to be Gram-negative on staining. Beyond these common features, organisms in the genus have great diversity in size, metabolic products and nutritional requirements.

In an investigation employing DNA homology experiments (Cummins \& Johnson, I971), we observed negligible homology among phenotypically similar butyric acid-producing 
Table I. Designations of the Clostridium strains used, sensitivity of their cells to lysozyme, $D N$ Aase activities in cell lysates, and the amount of growth in GMB and PYG media

Growth measured by $E_{580}+$

\begin{tabular}{|c|c|c|c|c|c|c|c|}
\hline \multirow[b]{3}{*}{$\begin{array}{c}\text { Species } \\
\text { no. }\end{array}$} & \multirow[b]{3}{*}{$\begin{array}{l}\text { Strain } \\
\text { no.* }\end{array}$} & & \multirow{3}{*}{$\begin{array}{l}\text { Lyso- } \\
\text { zyme } \\
\text { sensi- DNAase } \\
\text { tivity activity }\end{array}$} & \multirow{2}{*}{\multicolumn{2}{|c|}{ GMB medium }} & \multirow{2}{*}{\multicolumn{2}{|c|}{ PYG medium }} \\
\hline & & & & & & & \\
\hline & & Name & & $\begin{array}{c}\text { Ist } \\
\text { transfer }\end{array}$ & $\begin{array}{l}\text { 2nd } \\
\text { transfer }\end{array}$ & $\begin{array}{c}\text { Ist } \\
\text { transfer }\end{array}$ & $\begin{array}{l}\text { 2nd } \\
\text { transfer }\end{array}$ \\
\hline
\end{tabular}

A. Clostridia with subterminal spores, not liquefying gelatin

\begin{tabular}{|c|c|c|c|c|c|c|c|c|}
\hline \multirow[t]{2}{*}{ I } & 19398 & C. butyricum & + & + & $1 \cdot 30$ & $1 \cdot 70$ & $1 \cdot 52$ & $\mathrm{I} \cdot 30$ \\
\hline & $1622 \dagger$ & C. butyricum & + & + & . & . & . & . \\
\hline \multirow[t]{2}{*}{2} & 25752 & C. beijerinckii & + & - & . & . & . & . \\
\hline & 17778 & C. beijerinckii & + & - & . & . & . & . \\
\hline 3 & 25750 & C. oroticum & + & - & 0.46 & 0.00 & $1 \cdot 30$ & $1 \cdot 52$ \\
\hline 4 & $2575 \mathrm{I}$ & C. rectum & - & . & $\mathrm{I} \cdot 30$ & 0.01 & $I \cdot I 0$ & $0 \cdot 72$ \\
\hline \multirow[t]{2}{*}{5} & 25753 & C. paraperfringens & + & - & 0.13 & O.OI & $I \cdot 40$ & $1 \cdot 10$ \\
\hline & $3007 \dagger$ & C. paraperfringens & + & - & $0 \cdot 70$ & 0.00 & $1 \cdot 52$ & $I \cdot 70$ \\
\hline 6 & 14949 & C. rubrum & + & \pm & . & . & . & . \\
\hline 7 & $6010 \dagger$ & C. fallax & + & \pm & . & . & . & . \\
\hline 8 & 6013 & C. pasteurianum & + & \pm & $1 \cdot 30$ & $I \cdot 10$ & $1 \cdot 30$ & $1 \cdot 70$ \\
\hline 9 & I 2662 & C. sticklandii & . & . & 0.07 & . & 0.77 & 0.37 \\
\hline IO & 25755 & C. tyrobutyricum & + & - & 0.77 & 0.02 & $I \cdot 70$ & $\mathrm{I} \cdot 70$ \\
\hline II & 25522 & C. propionicum & + & - & 0.02 & . & 0.37 & $0 \cdot 27$ \\
\hline \multicolumn{9}{|c|}{ B. Clostridia with subterminal spores, liquefying gelatin } \\
\hline 12 & 25757 & C. ghoni & - & . & 0.23 & 0.01 & $1 \cdot 40$ & $\mathrm{I} \cdot 22$ \\
\hline I3 & 638 & C. bifermentans & - & . & 0.60 & 0.01 & 0.80 & 0.89 \\
\hline 14 & 9714 & C. sordellii & + & - & 0.54 & 0.01 & $1 \cdot 15$ & $I \cdot 30$ \\
\hline 15 & 25759 & C. lituseburense & + & \pm & 0.40 & $0.0 \mathrm{I}$ & 0.85 & $I \cdot 05$ \\
\hline 16 & 25760 & C. limosum & - & . & 0.02 & . & 0.74 & 0.18 \\
\hline 17 & 25774 & C. subterminale & + & + & 0.00 & . & 0.52 & 0.30 \\
\hline I 8 & $2576 \mathrm{I}$ & C. mangenoti & + & + & 0.07 & 0.00 & $0 \cdot 30$ & 0.30 \\
\hline 19 & 3584 & C. sporogenes & + & - & 0.28 & 0.00 & $1 \cdot 30$ & $I \cdot 40(1 \cdot 40)$ \\
\hline \multirow[t]{3}{*}{20} & 25763 & C. botulinum type A & - & + & 0.02 & . & $I \cdot 30$ & $I \cdot 30$ \\
\hline & 7949 & C. botulinum type B & - & + & 0.40 & 0.00 & $1 \cdot 30$ & $I \cdot 40$ \\
\hline & 25764 & C. botulinum type $\mathrm{F}$ & - & + & $0 \cdot 19$ & 0.05 & $1 \cdot 00$ & $1 \cdot 52$ \\
\hline $2 \mathrm{I}$ & 25768 & C. plagarum & + & - & $0.2 \mathrm{I}$ & 0.00 & $\mathrm{I} \cdot 40$ & $\mathrm{I} \cdot 30$ \\
\hline 22 & 824 & C. acetobutylicum & + & + & 0.70 & 0.02 & 0.49 & $0 \cdot 39$ \\
\hline 23 & 25770 & C. histolyticum & - & . & $0.0 \mathrm{I}$ & . & 0.68 & 0.64 \\
\hline 24 & 17777 & C. aurantibutyricum & + & - & $I \cdot 15$ & $0.54(0.14)$ & $1 \cdot 40$ & $1 \cdot 70$ \\
\hline \multirow[t]{7}{*}{20} & 25765 & C. botulinum type B & - & + & 0.28 & 0.02 & I. 52 & $I \cdot 52$ \\
\hline & 25766 & C. botulinum type $\mathrm{C}$ & - & + & . & . & $\cdot$ & . \\
\hline & $4528 \dagger$ & C. botulinum type $\mathrm{C}$ & - & + & 0.01 & 0.00 & $1 \cdot 70$ & $\mathbf{I} \cdot 70$ \\
\hline & 25767 & C. botulinum type D & - & + & 0.72 & 0.03 & $1 \cdot 40$ & $1 \cdot 52(0.72)$ \\
\hline & 9564 & C. botulinum type $\mathrm{E}$ & - & + & . & . & . & . \\
\hline & $2382 \dagger$ & C. botulinum type $\bar{F}$ & - & + & $0.0 \mathrm{I}$ & - & 0.46 & 0.52 \\
\hline & $6714 \dagger$ & C. botulinum type $\mathrm{G}$ & - & + & 0.07 & . & 0.72 & 0.55 \\
\hline \multirow[t]{3}{*}{25} & $1786 \mathrm{I}$ & C. novyi type A & - & + & 0.43 & 0.09 & 0.92 & $0.47(0.14)$ \\
\hline & 25758 & C. novyi type B & - & . & 0.48 & 0.01 & $I \cdot 30$ & $I \cdot 05$ \\
\hline & 27323 & C. novyi type $\mathrm{C}$ & - & . & $0.0 \mathrm{I}$ & 0.00 & $I \cdot I 5$ & 0.00 \\
\hline \multirow[t]{4}{*}{26} & I 3124 & C. perfringens type $\mathrm{A}$ & + & - & 0.52 & $0.0 \mathrm{I}$ & $1 \cdot 40$ & $I \cdot 40$ \\
\hline & 3626 & C. perfringens type $\mathrm{B}$ & + & - & . & $\cdot$ & $\cdot$ & - \\
\hline & 3628 & C. perfringens type $\mathrm{C}$ & + & - & . & . & . & . \\
\hline & 3629 & C. perfringens type $\mathrm{D}$ & + & - & . & . & . & . \\
\hline \multirow[t]{2}{*}{27} & 9650 & C. haemolyticum & - & . & 0.19 & 0.00 & $1 \cdot 40$ & $\mathrm{I} \cdot \mathrm{I} 5$ \\
\hline & $2167 \dagger$ & C. haemolyticum & . & . & 0.01 & 0.00 & $1 \cdot 30$ & 0.23 \\
\hline 28 & 17788 & C. felsineum & + & + & 0.06 & . & 0.04 & . \\
\hline 29 & 10092 & C. chauvoei & - & . & 0.39 & $0.18(0.00)$ & $\mathrm{I} \cdot 40$ & $\mathrm{I} \cdot 30$ \\
\hline 30 & I 2464 & C. septicum & + & . & $I \cdot 30$ & 0.09 & $1 \cdot 30$ & $1 \cdot 30$ \\
\hline $3 I$ & 9689 & C. difficile & . & . & 0.80 & 0.15 & $1 \cdot 40$ & $1 \cdot 30$ \\
\hline
\end{tabular}


Table I (cont.)

\begin{tabular}{|c|c|c|c|c|c|c|c|c|}
\hline \multirow[b]{3}{*}{$\begin{array}{c}\text { Species } \\
\text { no. }\end{array}$} & \multirow[b]{3}{*}{$\begin{array}{c}\text { Strain } \\
\text { no.* }\end{array}$} & \multirow[b]{3}{*}{ Name } & \multirow{3}{*}{$\begin{array}{l}\text { Lyso- } \\
\text { zyme } \\
\text { sensi- } \\
\text { tivity }\end{array}$} & \multirow[b]{3}{*}{$\begin{array}{l}\text { DNAase } \\
\text { activity }\end{array}$} & \multicolumn{4}{|c|}{ Growth measured by $E_{580}+$} \\
\hline & & & & & \multicolumn{2}{|c|}{ GMB medium } & \multicolumn{2}{|c|}{ PYG medium } \\
\hline & & & & & $\begin{array}{c}\text { Ist } \\
\text { transfer }\end{array}$ & $\begin{array}{l}\text { 2nd } \\
\text { transfer }\end{array}$ & $\begin{array}{c}\text { Ist } \\
\text { transfer }\end{array}$ & $\begin{array}{c}\text { 2nd } \\
\text { transfer }\end{array}$ \\
\hline \multicolumn{9}{|c|}{ C. Clostridia with terminal spores, not liquefying gelatin } \\
\hline 32 & 19403 & C. sphenoides & + & \pm & $1 \cdot 40$ & $0.85(0.96)$ & $1 \cdot 40$ & $\mathrm{I} \cdot 30$ \\
\hline 33 & 25771 & C. indolis & + & - & $1 \cdot 30$ & $0.66(0.70)$ & $1 \cdot 40$ & $1 \cdot 30(I \cdot 30)$ \\
\hline 34 & 25775 & C. scatologenes & + & . & $0 \cdot 74$ & 0.60 & $1 \cdot 52$ & $\mathrm{I} \cdot 40$ \\
\hline 35 & 25776 & C. malenominatum & + & . & 0.23 & 0.10 & 0.34 & 0.34 \\
\hline 36 & 14573 & C. tertium & . & . & 0.60 & $0 \cdot 0 \mathrm{I}$ & $1 \cdot 00$ & 0.82 \\
\hline 37 & 25778 & C. sartagoformum & + & - & 0.77 & 0.06 & $1 \cdot 70$ & $1 \cdot 40$ \\
\hline 38 & 15832 & C. cellobioparum & + & . & 0.89 & $0.0 \mathrm{I}$ & $I \cdot 30$ & $1 \cdot 30$ \\
\hline 39 & 25773 & C. thermosaccharolyticum & + & - & $\cdot$ & . & $1 \cdot 30$ & $1 \cdot 40$ \\
\hline 40 & 25779 & C. pseudotetanicum & + & - & $\mathrm{I} \cdot 40$ & $1 \cdot 40(I \cdot 30)$ & $1 \cdot 70$ & $1 \cdot 52$ \\
\hline $4 I$ & 25777 & C. carnis & + & + & $0 \cdot 96$ & 0.12 & $\mathrm{I} \cdot \mathrm{I} 5$ & $1 \cdot 15(I \cdot 40)$ \\
\hline 42 & $1586 \dagger$ & C. paraputrificum & + & - & $1 \cdot 15$ & $1 \cdot 10(0 \cdot 47)$ & $I \cdot 70$ & $1 \cdot 52$ \\
\hline 43 & 13725 & C. aminovalericum & + & . & $\mathrm{I} \cdot 30$ & 0.08 & $\mathrm{I} \cdot 70$ & $I \cdot 70$ \\
\hline 44 & 14880 & C. glycolicum & + & \pm & $0 \cdot 74$ & 0.03 & $1 \cdot 30$ & $I \cdot 30$ \\
\hline 45 & $2578 \mathrm{I}$ & C. sporosphaeroides & + & - & 0.04 & $\cdot$ & 0.30 & 0.29 \\
\hline 46 & 17787 & C. cochlearium & + & - & 0.70 & 0.00 & $\mathrm{I} \cdot 30$ & $I \cdot 30$ \\
\hline \multirow[t]{2}{*}{47} & 25582 & C. ramosum & + & + & $1 \cdot 52$ & I. OO $(0 \cdot 89)$ & $I \cdot 70$ & $\mathrm{I} \cdot 52$ \\
\hline & $5027 \mathrm{~F} \dagger$ & C. ramosum & . & . & $I \cdot 52$ & 0.60 & $1 \cdot 40$ & $\mathrm{I} \cdot 15$ \\
\hline \multirow[t]{3}{*}{48} & $1450 \mathrm{I}$ & C. innocuum & + & - & $1 \cdot 40$ & $0.57(0.01)$ & $I \cdot 70$ & $I \cdot 70$ \\
\hline & $2019 t$ & C. innocuum & . & . & $\cdot$ & . & . & . \\
\hline & $2020 \dagger$ & C. innocuum & . & . & . & . & . & . \\
\hline 49 & 25849 & C. barkeri & - & . & 0.70 & $0 \cdot 2 \mathrm{I}$ & $1 \cdot 40$ & $I \cdot 52$ \\
\hline 50 & 25782 & C.perenne & + & \pm & 0.68 & 0.02 & $1 \cdot 72$ & $I \cdot 52$ \\
\hline \multicolumn{9}{|c|}{ D. Clostridia with terminal spores, liquefying gelatin } \\
\hline $5 I$ & 25783 & C. cadaveris & + & - & $0 \cdot 36$ & 0.03 & $I \cdot 40$ & $I \cdot 40$ \\
\hline 52 & 17794 & C. lentoputrescens & + & + & 0.07 & 0.66 & 0.66 & 0.68 \\
\hline 53 & 25784 & C. putrificum & + & \pm & 0.21 & 0.01 & $I \cdot 30$ & $\mathrm{I} \cdot 52$ \\
\hline 54 & 25647 & C. oceanicum & + & \pm & 0.68 & 0.00 & $1 \cdot 40$ & $1 \cdot 30$ \\
\hline 55 & 8033 & C. tetani & + & - & 0.40 & 0.00 & $I \cdot 15$ & 0.96 \\
\hline 56 & 25786 & C. putrefaciens & . & . & $\cdot$ & . & . & . \\
\hline
\end{tabular}

clostridia. However, because of the conservation of rRNA cistrons, rRNA homology experiments might prove useful in establishing subgroups within this large diverse genus. The results of such a study, employing strains from fifty-six clostridial species, are reported in this paper.

\section{METHODS}

Organisms. These are listed in Table I. Most were employed as reference organisms by L. DS. Smith \& G. Hobbs (I974) in preparing the Clostridium section for the 8th edition of Bergey's Manual. The species numbers (Table I) are those designated by Smith and Hobbs, and the strains are designated by American Type Culture Collection (ATCC) numbers or by Virginia Polytechnic Institute and State University (VPI) numbers.

The organisms were maintained on chopped-meat medium (Anaerobe Laboratory Manual, 1973) and cultures for the isolation of unlabelled DNA and RNA were grown in peptone-yeast extract-glucose medium (PYG) as described by Cummins \& Johnson (I97I). 
Labelled RNA preparations were obtained by growth in a low peptone medium (Cummins \& Johnson, I97I) supplemented with $\left[{ }^{3} \mathrm{H}\right]$ uracil (I $\mathrm{mCi} / 200 \mathrm{ml}$; New England Nuclear, Boston, Massachusetts, U.S.A.). When the culture reached late exponential phase, Io $\mathrm{mg}$ of unlabelled uracil was added and incubation continued for a further $15 \mathrm{~min}$. The RNA was then isolated as described below.

$R N A$ isolation. A modification of the method of Kirby (1967) was used. Bacteria were suspended in $0.5 \%$ disodium naphthalene 1,5-disulphonate and disrupted by passage through a French pressure cell $\left(1 \cdot \mathrm{I} \times 10^{8} \mathrm{~Pa}\right)$ into the phenol-cresol mixture. After two extractions with phenol-cresol, $20 \times$ standard saline citrate (SSC) (where $\mathrm{I} \times \mathrm{SSC}=0.15 \mathrm{M}-$ $\mathrm{NaCl}$ and $0.015 \mathrm{M}$-sodium citrate, $\mathrm{pH} 7 \cdot 0$ ) was added ( $1: 20)$ to the aqueous phase and RNA precipitated with 2 volumes of ethanol and collected by centrifugation. The RNA preparations were then dissolved in $\mathrm{I} \times \mathrm{SSC}(20 \mathrm{ml})$ and precipitated again with ethanol. This was repeated until phenol could no longer be detected in the ethanol supernatant by measuring $E_{270}$.

The glassware used for the isolation and storage of the RNA preparations was first autoclaved submersed in $0.1 \%$ Isoclean (Isolab Incorporated, Akron, Ohio, U.S.A.), rinsed, and then autoclaved empty. The buffers and solutions (excluding organic solvents) were autoclaved and stored with a few added drops of chloroform. Without these precautions the RNA preparations were progressively degraded by residual RNAase during storage at $-20^{\circ} \mathrm{C}$.

Sucrose gradients. Sucrose gradients ( 4 to $20 \%$ ) were prepared with RNAase-free sucrose (Schwarz/Mann, Orangeburg, New York, U.S.A.) using autoclaved $\mathrm{I} \times$ SSC. The $30 \mathrm{ml}$ gradients were layered with approximately I mg RNA and centrifuged in a Spinco SW $25 . \mathrm{I}$ rotor at $63000 \mathrm{~g}$ and $8{ }^{\circ} \mathrm{C}$ for $16 \mathrm{~h}$. After centrifugation, the tubes were pierced (Buchler Universal piercing unit, Fort Lee, New Jersey, U.S.A.) and the samples passed through a flow cell $(0.5 \mathrm{~cm}$ light path; Pyrocell, Westwood, New Jersey) in a Gilford Model 2400 spectrophotometer (Gilford Laboratories, Oberlin, Ohio). The $23 \mathrm{~S}$ and $16 \mathrm{~S}$ components were collected, dialysed against buffer containing $0^{\cdot} \mathrm{I} \times \mathrm{SSC}$ and $0.5 \mathrm{mM}-\mathrm{HEPES}, \mathrm{pH} 7 \cdot 0$ (Calbiochem), sheared by two passages through a French pressure cell $\left(I \cdot I \times I 0^{8} \mathrm{~Pa}\right)$, and heated for $5 \mathrm{~min}$ in a boiling water bath. The RNA preparations were adjusted to $20 \mu \mathrm{g} / \mathrm{ml}$ using the $0 . \mathrm{I} \times \mathrm{SSC}-\mathrm{HEPES}$ buffer and stored at $-80^{\circ} \mathrm{C}$.

Competitor RNA preparations. The stock RNA preparations were diluted to $\mathrm{I} \mathrm{mg} / \mathrm{ml}$ in $0 \cdot \mathrm{I} \times \mathrm{SSC}-\mathrm{HEPES}$ buffer $\mathrm{pH} 7{ }^{\circ}$, sheared by two passages through a French pressure cell $\left(\mathrm{I} \cdot \mathrm{I} \times 10^{8} \mathrm{~Pa}\right)$ and heated for $5 \mathrm{~min}$ in a boiling water bath. After rapid cooling in an ice bath, the preparations were stored at $-80{ }^{\circ} \mathrm{C}$.

$D N A$ isolation. Isolation of DNA from detergent or lysozyme-sensitive cells and from lysozyme-resistant cells has been described (Cummins \& Johnson, 197I; Johnson \& Cummins, 1972).

Percentage guanine + cytosine. The $\% \mathrm{GC}$ of the DNA preparations was determined by their thermal melting points (Marmur \& Doty, I962; Johnson \& Cummins, 1972).

DNA immobilization. The immobilization of denatured DNA on nitrocellulose membrane filters has been described (Gillespie \& Spiegelman, I965; Johnson \& Ordal, I968). At the time of an experiment, I cm diam filters were cut from the $15 \mathrm{~cm}$ diam. filters and preincubated in the Denhardt mixture (Denhardt, 1966) as described by Johnson \& Ordal (1968) and Johnson et al. (1970).

$R N A$ competition experiments. Reaction vials ( $4 \mathrm{ml}$ ) contained $\mathrm{I} \mu \mathrm{g}$ of labelled RNA and $\mathrm{o}$, 50 or I00 $\mu \mathrm{g}$ of competitor RNA in a total volume of $0.35 \mathrm{ml}$ of $2 \times$ SSC-0.0 I M-HEPES buffer $\mathrm{pH} 7 \cdot 0$. After the addition of a pre-incubated membrane, the vials were incubated for 15 to 
$\mathrm{I} 6 \mathrm{~h}$ at $70{ }^{\circ} \mathrm{C}$ (temperatures of 65 and $75^{\circ} \mathrm{C}$ were used in some experiments, as indicated in Results). After incubation, the membranes were placed into a compartmented washing chamber (constructed from Plexiglass) and washed for $5 \mathrm{~min}$ in each of two $300 \mathrm{ml}$ volumes of $2 \times \mathrm{SSC}$ held at the incubation temperature. To remove unpaired segments of rRNA from the hybrids, the washing chamber was then placed into $80 \mathrm{ml}$ of RNAase mixture ( $50 \mu \mathrm{g}$ pancreatic RNAase and 2.5 units TI RNAase $/ \mathrm{ml} 2 \times \mathrm{SSC}$ ) and incubated for $30 \mathrm{~min}$ at $35{ }^{\circ} \mathrm{C}$. The membranes were then washed in a third $300 \mathrm{ml}$ volume of $2 \times \mathrm{SSC}$. After drying, the membranes were mounted on insect pins and the radioactivity measured in a liquid scintillation counter. The percentage homology values were calculated as described by Johnson \& Cummins (I972), but using c.p.m. RNA hybridized/ $\mu$ g membrane-bound DNA rather than assuming a constant level of membrane-bound DNA. The amount of DNA retained on the membrane was measured by the diphenylamine method (Giles \& Myers, I965). The membranes were removed from the scintillation vials and, after the toluene had evaporated, were placed into $\mathrm{I} 6 \times 125 \mathrm{~mm}$ screw-cap tubes. Perchloric acid $(2 \mathrm{ml}$ of $10 \%$, $\mathrm{w} / \mathrm{v}$ ) was added and the DNA removed quantitatively from the membranes by heating at $70{ }^{\circ} \mathrm{C}$ for $10 \mathrm{~min}$. The membranes were removed from the tubes (this consistently removed about $5 \%$ of the DNA) and the diphenylamine assay completed. The homologous competitor RNA levels of 50 and $100 \mu \mathrm{g}$ depressed the binding of the labelled RNA by 97 and $98 \%$, respectively.

The thermo-stability profiles of RNA-DNA hybrids were determined in a manner similar to that used for DNA-DNA duplexes (Anderson \& Ordal, I972; Johnson \& Ordal, 1968).

Nutritional requirements. A glucose-mineral salt base medium (GMB) containing $0.05 \%(\mathrm{w} / \mathrm{v})$ cysteine, $\mathrm{I} .0 \%(\mathrm{w} / \mathrm{v})$ glucose, $0.5 \%(\mathrm{w} / \mathrm{v}) \mathrm{NaHCO}_{3}$ and a vitamin mixture (Pittman \& Bryant, 1964) was employed for determining minimal nutritional requirements (Cummins \& Johnson, 197I). Peptone-yeast extract-glucose medium (PYG) (Anaerobe Laboratory Manual, 1973) was also used, and supported the growth of many of those organisms having complex growth requirements. The media were dispensed in $5 \mathrm{ml}$ amounts under $\mathrm{CO}_{2}$ into I $8 \times 150 \mathrm{~mm}$ culture tubes which were then closed by rubber stoppers. Five drops of a culture grown on chopped meat medium were used to inoculate the first transfer into the test medium. For the 2 nd and 3 rd transfers, 5 drops were serially transferred from test medium cultures. The cultures were incubated at $37{ }^{\circ} \mathrm{C}$ and the $E_{580}$ measured at 24 and $48 \mathrm{~h}$ using a Spectronic 20 spectrophotometer. The higher of the extinction values was recorded in Table $\mathrm{I}$ for the Ist and 2 nd transfers. In the few cases where a 3 rd transfer was made, the results are given in parentheses after the 2 nd transfer results.

Sensitivity of cell walls to lysozyme. Overnight cultures in PYG medium (25 or $50 \mathrm{ml})$ were centrifuged and the cells suspended in $2 \mathrm{ml}$ of $0.15 \mathrm{M}-\mathrm{NaCl}-0.0 \mathrm{I} \mathrm{M}-\mathrm{EDTA}$ buffer pH 8.0 (Marmur, I96I). Lysozyme (I to $2 \mathrm{mg}$ ) was added to each suspension, followed by incubation at $37{ }^{\circ} \mathrm{C}$. Portions were removed at various times from $5 \mathrm{~min}$ up to $\mathrm{I} \cdot 5 \mathrm{~h}$ and wall digestion tested by adding $\mathrm{I}$ or 2 drops of $20 \%(\mathrm{w} / \mathrm{v})$ sodium lauryl sulphate (SLS). A translucent clearing of the cell suspension was recorded as positive for wall digestion by the lysozyme.

DNAase activity. This was estimated in cell lysates by the lack of or loss of viscosity or, in other cases, by the inability to isolate alcohol-precipitable DNA from physically disrupted cells. 
Table 2. Effect of endogenous RNAase activity on the $23 S R N A$ of $C$. carnis

\begin{tabular}{|c|c|c|c|c|}
\hline \multirow[b]{3}{*}{$\begin{array}{l}\text { Competitor } \\
\text { RNA source }\end{array}$} & \multirow[b]{3}{*}{ Strain no. } & \multicolumn{3}{|c|}{ Percentage homology with $23 \mathrm{~S}$ rRNA of } \\
\hline & & \multicolumn{2}{|c|}{ C. carnis } & \multirow[t]{2}{*}{ C. perfringens } \\
\hline & & $\begin{array}{c}\text { Ist } \\
\text { preparation }\end{array}$ & $\begin{array}{c}\text { 2nd } \\
\text { preparation }\end{array}$ & \\
\hline C. carnis & $25777^{*}$ & 100 & 100 & 77 \\
\hline C. perfringens type $\mathrm{A}$ & $13124^{*}$ & 98 & 72 & 100 \\
\hline C. botulinum type $\mathrm{E}$ & $2 \mathrm{I} 57^{\dagger}$ & 98 & 72 & - \\
\hline C. lituseburense & $25759^{*}$ & 68 & 20 & 27 \\
\hline C. tetani & $10799^{*}$ & 75 & $2 I$ & 33 \\
\hline C. mangenoti & $25761 *$ & 65 & 22 & 22 \\
\hline Escherichia coli $\mathbf{\text { в }}$ & & 49 & 5 & - \\
\hline
\end{tabular}

\section{RESULTS}

RNA competition experiments were performed at various incubation temperatures with and without RNAase treatment after incubation. Homology values were the same at incubation temperatures of 65,70 and $75{ }^{\circ} \mathrm{C}$, but since there was increased leaching of DNA from the membrane at $75^{\circ} \mathrm{C}$ the intermediate temperature of $70{ }^{\circ} \mathrm{C}$ was used for the rest of the experiments. Although the RNAase treatment was employed in all of the experiments reported in Tables 2, 3 and 4, the homology values were the same when no RNAase was used. The RNAase removed approximately $30 \%$ of the labelled material from each filter.

\section{Non-reciprocal homology values}

Early in the study it was observed that homology values were not reciprocal between Clostridium carnis (ATCC25777) RNA, and other RNA preparations. Clostridium carnis RNA competed with the $23 \mathrm{~S}$ rRNA of $C$. perfringens (ATCCI 3124 ), $77 \%$ as compared with the homologous $C$. perfringens RNA; however, in the reciprocal experiment, $C$. perfringens RNA competed $98 \%$ as well as the homologous $C$. carnis RNA with the $23 \mathrm{~S}$ rRNA of $C$. carnis (Table 2). Other RNA preparations also competed to a higher extent than expected. Therefore, another sample of the stock $C$. carnis $\left[{ }^{3} \mathrm{H}\right] \mathrm{RNA}$ was centrifuged into a sucrose gradient as described in Methods. The $23 \mathrm{~S}$ RNA collected from this gradient was designated '2nd preparation' and the competition experiments repeated (Table 2). The increased discriminatory power of the heterologous competitor RNA preparations, indicated that the initial preparation of ${ }^{3} \mathrm{H}{ }_{23} \mathrm{~S} C$. carnis rRNA was degraded to such an extent that the specificity of the hybrids was depressed. To test this, thermal stability profiles of the homologous and heterologous $C$. carnis and $C$. perfringens hybrids were determined. The $\mathrm{T}_{\mathrm{m}(e)}$ value (the temperature at which one-half of the RNA-DNA hybrid molecules have dissociated) for the homologous $C$. carnis hybrids (Ist $23 \mathrm{~S}$ rRNA preparation) was $14{ }^{\circ} \mathrm{C}$ lower than for the homologous $C$. perfringens, and $10.5{ }^{\circ} \mathrm{C}$ lower than for the $C$. carnis DNA-C. perfringens RNA hybrids. The $\mathrm{T}_{\mathrm{m}(\mathrm{e})}$ values of $C$. carnis hybrids using the ist RNA preparation were similar with both kinds of DNA. Such results would be expected if the preparation giving the anomalous results consisted of very short fragments of RNA (Niyogi, 1969; McCarthy, 1967). This problem of RNA degradation has been largely eliminated by the precautions described in Methods, although the 20 to $30 \%$ competition given by RNA from the 'unrelated' control organisms may indicate some degradation. 
Nutritional requirements, lysozyme sensitivity and DNAase activities

In addition to differences in morphology, fermentative capabilities and fermentation products (Smith \& Hobbs, 1974; Mead, 197I; Moore, Cato \& Holdeman, 1966), organisms in the genus Clostridium vary greatly with respect to growth requirements, susceptibility of the cell walls to lysozyme, and in the release of deoxyribonucleases upon disruption of the cells. These variables have caused difficulties in homology experiments among certain of these organisms (Lee \& Rieman, I $970 a, b$ ). It appeared that a survey of some of these characteristics would be useful for the interpretation of our results and for future homology studies. This information is in Table I. The species numbers are those of Smith \& Hobbs (1974), and the subheadings A, B, C and D correspond to their Tables I5-9, I5-12, 15-15 and 15-18.

The sensitivity of the cell walls to lysozyme and the release of DNAase activity are only qualitative measurements obtained under the usual conditions for DNA isolation. Fortythree of the species were readily made sensitive to detergent by lysozyme. Preheating the organisms to $60{ }^{\circ} \mathrm{C}$, to inactivate DNAases, decreased or eliminated the action of the lysozyme. In most cases if the cells could not be made detergent-sensitive with lysozyme, there was no attempt to measure DNAase activity; however, in some cases the organisms from 2.51 cultures were disrupted with either glass beads (Johnson \& Cummins, 1972) or with a French pressure cell. Lysates from cultures recorded as negative for DNAase remained highly viscous for several hours. The cultures recorded as ' \pm ' were those where the isolated DNA appeared to be partially degraded, as indicated by the inability to collect the ethanol-precipitated DNA on a glass stirring rod. Other cultures that were recorded as DNAase positive were those from which only small amounts of DNA were obtained when the cells were physically opened. Examples of these were C. botulinum, C. barkeri and C. novyi type A.

Ten of the clostridial species grew well through two transfers in GMB medium (Table I), thus exhibiting minimal nutritional requirements. An additional six species grew well on the first transfer in GMB medium but not on subsequent transfers, indicating that they may have requirements for certain amino acids or additional vitamins that were supplied by the chopped meat inoculum. Other organisms grew poorly if at all in the GMB medium but grew well in the PYG, which suggested requirements for amino acids that were in low concentrations in the inoculum. Other species, e.g. C. propionicum, C. limosum, C. subterminale, $C$. mangenoti and $C$. malenominatum, grew poorly in the PYG medium. These species are non-saccharolytic but do ferment amino acids, which could be in limiting concentrations in the PYG medium.

\section{Clostridia with DNA having low \% GC values}

Homology data for most of the species are shown in Table 3. The DNA preparations from these organisms range from 24 to $32 \% \mathrm{GC}$, with the majority of them being 26 to $28 \%$ GC. The RNA preparations from organisms in group I (the largest group) competed to the extent of $50 \%$ or more with labelled RNA from one or more of the reference strains $C$. butyricum, $C$. perfringens type A, C. carnis, $C$. sporogenes, $C$. novyi type $\mathrm{A}$ and $C$. pasteurianum. The species in this group were first placed in descending order of homology to the reference strain of the type species of the genus, C. butyricum (ATCCI9398). Some minor adjustments in the order were made so that organisms having high homology with a given reference strain were grouped together. Subgroups have been designated within group I, based either on very high homology to a given reference RNA or on the pattern of homologies with the six reference RNA preparations. Ribonucleic acid preparations from 


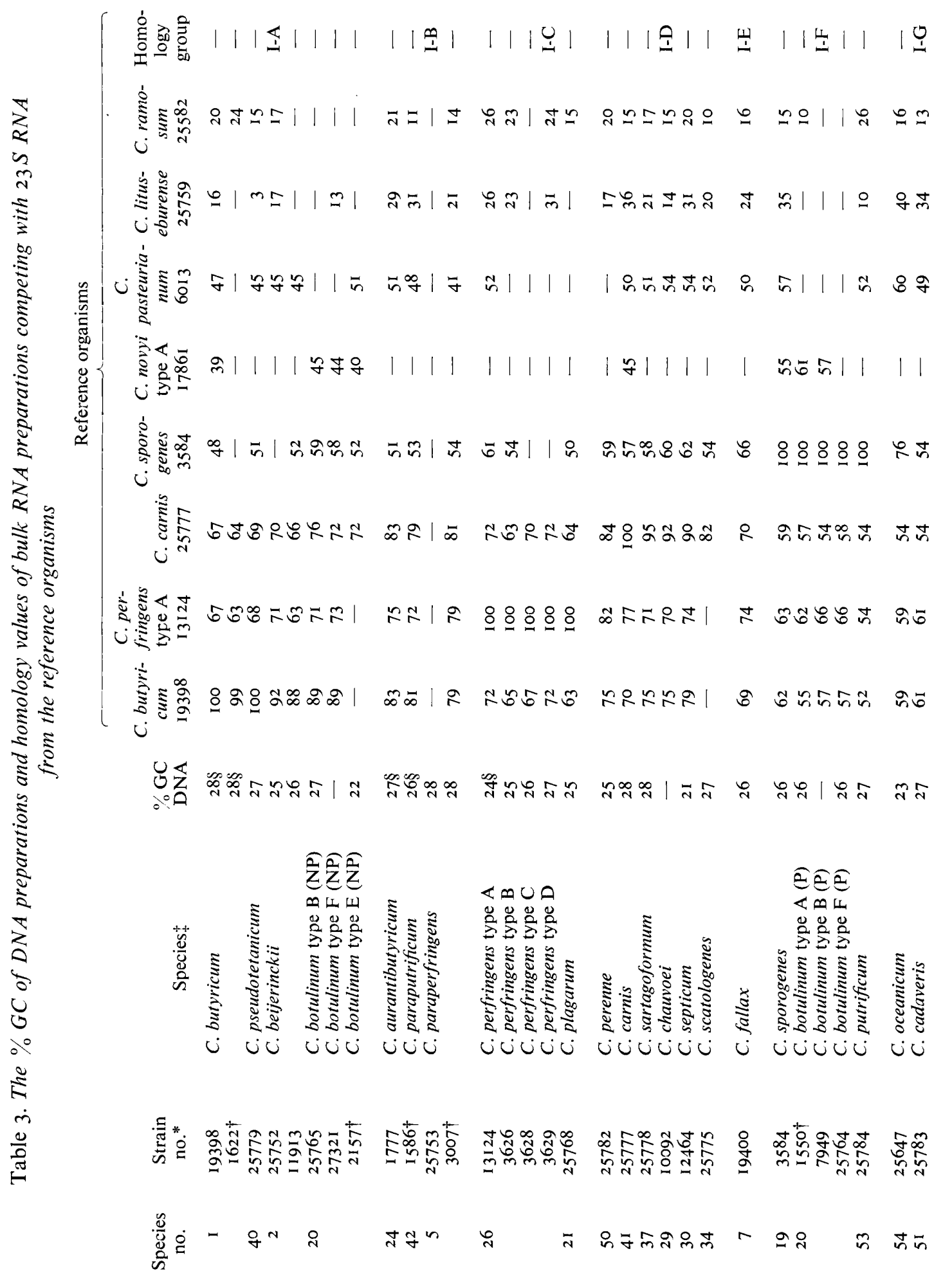




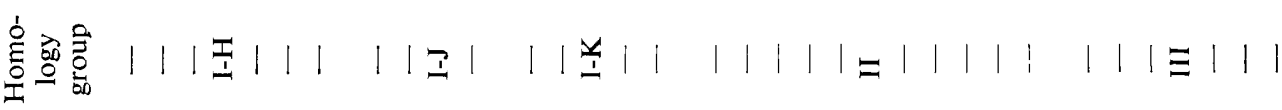

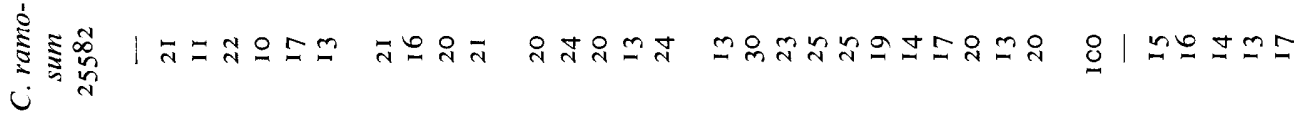

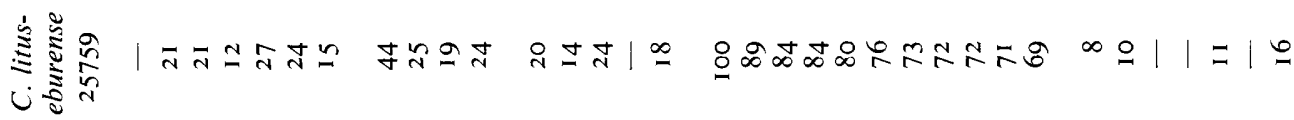

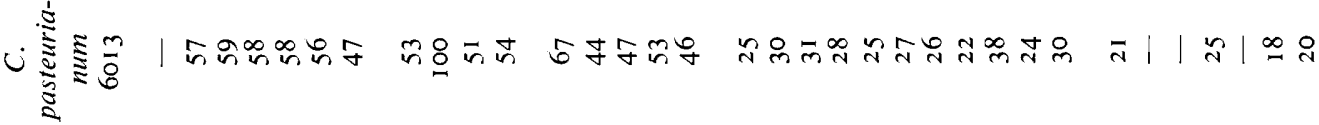
ن

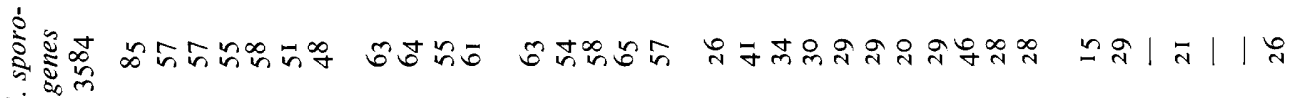
$\checkmark$

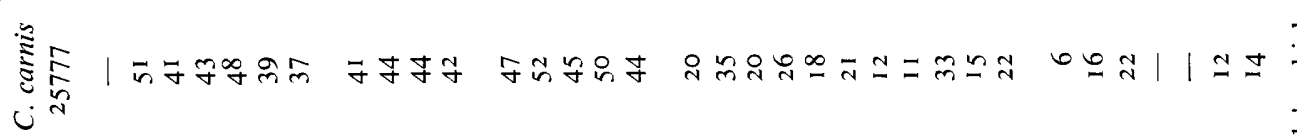

7.ำ

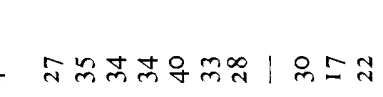

$\Sigma\left(\frac{4}{4}|\hat{4}|\right.$

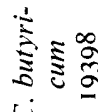

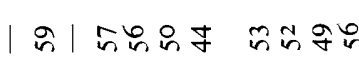

$\operatorname{cn} \approx n$

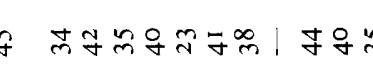
U

落
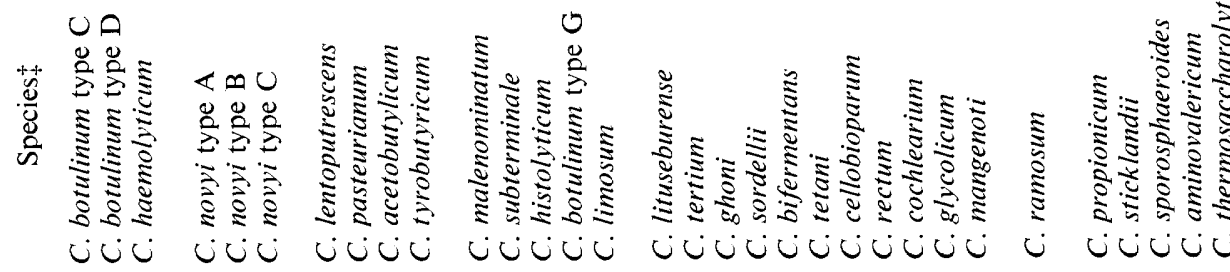

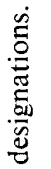

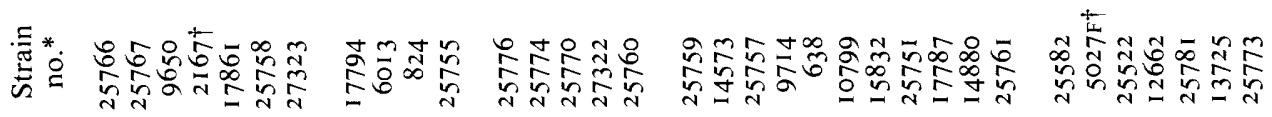

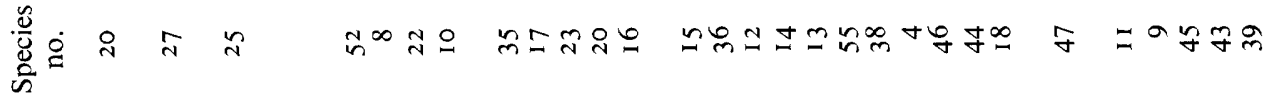


Table 4. Nucleic acid homologies using C. innocuum (ATCCI 45OI) as reference organism

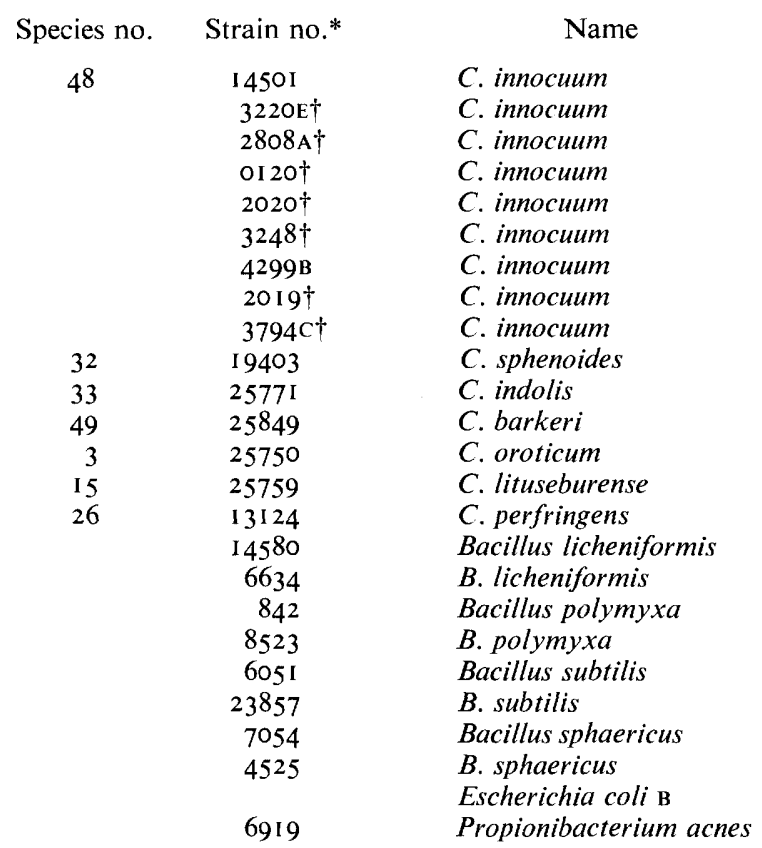

\begin{tabular}{|c|c|c|}
\hline \multirow[b]{2}{*}{$\% \mathrm{GC}$} & \multicolumn{2}{|c|}{$\%$ homology } \\
\hline & DNA/DNA & RNA/DNA \\
\hline 44 & IOO & 100 \\
\hline 44 & 93 & 99 \\
\hline - & 86 & - \\
\hline - & 84 & 一 \\
\hline 44 & 79 & - \\
\hline - & 76 & 一 \\
\hline- & 76 & - \\
\hline 43 & 75 & - \\
\hline- & $4 I$ & 99 \\
\hline $4 \mathrm{I}$ & - & 25 \\
\hline 44 & - & 22 \\
\hline 45 & 一 & IO \\
\hline 44 & 一 & 38 \\
\hline 26 & - & 30 \\
\hline 24 & - & 30 \\
\hline 46 & 0 & $3 I$ \\
\hline 44 & 0 & 30 \\
\hline 45 & - & 23 \\
\hline 43 & 0 & 28 \\
\hline 43 & 8 & $3 \mathrm{I}$ \\
\hline 43 & 3 & 30 \\
\hline 40 & 14 & 26 \\
\hline 40 & 10 & 24 \\
\hline 52 & - & I 6 \\
\hline 59 & - & 27 \\
\hline
\end{tabular}

* ATCC strain designations except those marked $\uparrow$, which are VPI numbers.

the II species in the other major group (group II) range in homology from 69 to $89 \%$ with the ${ }_{23} \mathrm{~S}$ rRNA of $C$. lituseburense. Organisms in these two major groups have cross RNA homologies of 20 to $40 \%$. Six additional species have essentially background homology (Table 3) with the group I and II reference strains. One of the six, C. ramosum (ATCC25582), was used as a reference but it does not appear to be significantly related to any other species of Clostridium tested.

\section{Clostridia with DNA having high \% GC values}

Five species of Clostridium had DNA with 4I to $45 \%$ GC. Homology experiments using these organisms are shown in Table 4. Clostridium innocuum (ATCCI45OI) was used as the reference organism for both DNA and RNA homology experiments. Other strains of C. innocuum have 75 to $93 \%$ DNA homology with the reference strain with the exception of VPI strain 3794C which shows $4 \mathrm{I} \%$. However, rRNA preparations from VPI strains $3220 \mathrm{E}(93 \%$ DNA homology) and 3794C both show $99 \%$ homology with the $23 \mathrm{~S}$ rRNA from the reference organism (Table 4). The other four species of high $\% \mathrm{GC}$ clostridia showed little or no homology with $C$. innocuum $23 \mathrm{~S}$ rRNA as did RNA from several Bacillus species having similar \% GC DNA. Therefore, it does not appear that the Clostridium species having $4 \mathrm{I}$ to $45 \%$ GC DNA constitute an interrelated group of organisms, nor, at this level of detection, do they show any relatedness with Bacillus species having similar $\%$ GC values. 


\section{DISCUSSION}

A full range of rRNA similarities, from experimental background levels to complete homology, was found among the species in the genus. The majority of the species fit into homology groups I and II (Table 3). Most of these have DNA with 26 to $28 \%$ GC. Species in group III also have DNA with similar $\%$ GC values but have little or no similarity with groups I and II. Five additional species are unique in that they have DNA with $4 \mathrm{I}$ to $45 \%$ GC. The $\%$ GC values are similar to those obtained in other laboratories. Our values for C. butyricum and C. pasteurianum are about $3 \%$ lower than the values obtained by Tonomura, Malkin \& Rabinowitz (1965). Lee \& Riemann (1970a, b) found the various $C$. botulinum strains to have $\% \mathrm{GC}$ values of 28 to 30 , whereas most of our values ranged from 26 to $27 \%$ GC. Three separate isolations of C. botulinum type E (VPI strain 2157) DNA resulted in DNA preparations having apparent \% GC values of 20, 2I and 22. At present these relatively low values are unexplained. The results of Stadtman et al. (1972) show the greatest variance with ours in that they found $C$. barkeri to have DNA with 55 to $58 \% \mathrm{GC}$. The buoyant density method of $\% \mathrm{GC}$ determination may be useful in resolving this discrepancy.

Homology group I. In general, the species in group I have $50 \%$ or more homology with the $23 \mathrm{~S} \mathrm{rRNA}$ of $C$. butyricum. Three species are slightly lower but in two cases have more than $50 \%$ homology with other group I reference organisms. The majority of these species produce butyric acid as a major fermentation product from glucose. Group I has been subdivided into Io subgroups to facilitate the discussion and to group those species that are or may be the most closely related.

Group I-A consists of $C$. butyricum and $C$. pseudotetanicum, which have quite minimal growth requirements (Table I), and $C$. beijerinckii and the non-proteolytic $C$. botulinum types B, F and E, which fail to grow in the absence of peptone and yeast extract (Table I; Cummins \& Johnson, 1971). The species listed as C. rubrum (Smith \& Hobbs, 1974) would also be in this group as it is a C. butyricum (Cummins \& Johnson, 197I). Clostridium beijerinckii and the $C$. botulinum types have very similar homologies to the reference strains in Table 3, which suggests that they may be very closely related; however, this can be clarified only by using one of them as a reference organism.

The I-B group is based on species having similar homology patterns with the reference organisms. Smith \& Hobbs (1974) separate C. aurantibutyricum and C. paraputrificum on the basis of spore location and gelatin liquefaction; however, the substrates utilized (carbohydrates and sugar alcohols) are nearly identical. Their growth patterns on GMB medium (Table 1) are also similar. Clostridium paraperfringens is phenotypically more like the organisms in group I-C ( $C$. perfringens and $C$. plagarum) in that it has complex growth requirements (Table $\mathrm{I}$ ) and is non-motile.

The $23 \mathrm{~S}$ rRNAs of $C$. perfringens and $C$. plagarum are $100 \%$ homologous. Toxin production, casein digestion and lecithinase activity have been the major characteristics used to distinguish them (Anaerobe Laboratory Manual, 1973; Smith \& Hobbs, 1974).

Although $C$. perenne is placed in group I-D because of a slightly higher homology to $C$. carnis than to $C$. perfringens, it is also non-motile. The rest of the species in group I-D have $90 \%$ or more homology with C. carnis. Both C. carnis and C. sartagoformum have terminal spores and are differentiated on mannitol and trehalose fermentation (Smith \& Hobbs, 1974). Clostridium carnis is also aero-tolerant. Both $C$. chauvoei and $C$. septicum have subterminal spores and their other phenotypic traits are very similar. Clostridium scatalogenes is morphologically and nutritionally quite similar to the other species in I-D but has a much more complex pattern of fermentation products (Anaerobe Laboratory Manual, 1973). 
Clostridium fallax (group I-E) appears to stand alone, having moderately high homologies with several of the group I reference strains.

A close relationship between $C$. sporogenes and the proteolytic $C$. botulinum types B and F (group I-F) has been demonstrated previously by DNA-DNA homology experiments (Lee \& Riemann, 1970 $b$; Wu, Riemann \& Lee, 1972). Also having 100\% rRNA homology with $C$. sporogenes is $C$. putrificum. Species in group I-F all produce a complex mixture of fermentation products from PYG medium and are proteolytic (Anaerobe Laboratory Manual, 1973).

Clostridium oceanicum and C. cadaveris (group I-G) have similar homologies with the reference strains and have many phenotypic traits in common (Anaerobe Laboratory Manual, 1973; Smith \& Hobbs, 1974). It is also of interest to note that these two species ferment various amino acids in the absence of glucose, which results in a complex array of fermentation acids. Glucose, however, represses these catabolic pathways and much less complex patterns of acids result when glucose is present (Anaerobe Laboratory Manual, 1973).

High levels of rRNA homology were found for $C$. botulinum types C and D and C. haemolyticum with $C$. novyi type A (group I-H). All three species have complex growth requirements (Table I) and utilize similar substrates (Anaerobe Laboratory Manual, I973; Smith \& Hobbs, 1974). The distinct toxins produced by each of these organisms have been used to differentiate among them. Some of these cistrons specifying toxins are carried by infecting phage (Inoue \& Iida, 1970; Eklund et al. 1971; Eklund, Poysky \& Reed, 1972; Eklund \& Poysky, I974).

The species in group I-J appear to be quite distinct from each other. Although C. lentopurescens and C. acetobutylicum have similar homologies to $C$. pasteurianum, the former has less stringent nutritional requirements than the latter (Table I).

The species in group I-K (C. subterminale, $C$. histolyticum, $C$. botulinum type $\mathrm{G}$ and C. limosum) are distinct from those in all other group I subgroups in that they do not ferment carbohydrates and the major by-product of metabolism is acetic acid.

Homology group II. The group II species have from 69 to $89 \%$ homology to the $23 \mathrm{~S}$ rRNA of C. lituseburense (ATCC25759). Although as a group these species have greater homogeneity of $23 \mathrm{~S}$ RNA cistrons than those in group I, it is not as homogeneous as some of the subgroups. Additional homology experiments using strains from other species as reference organisms would probably reveal subgroups. All of the species have complex nutritional requirements (Table $\mathrm{I}$ ) and acetic acid is usually a major product of glucose fermentation although in many cases the array of fermentation acids is quite complex (Anaerobe Laboratory Manual, I973). The majority of the group II species either do not ferment carbohydrates or tend to lower only slightly the $\mathrm{pH}$ of carbohydrate-containing media (Anaerobe Laboratory Manual, 1973), C. tertium and C. cellobioparum being the only ones that can substantially lower the $\mathrm{pH}$ of media containing certain carbohydrates. Clostridium ghoni, $C$. sordellii and $C$. bifermentans have very similar homologies to C. lituseburense (Table 3). They also have similar morphology, and have complex patterns of fermentation acids (Anaerobe Laboratory Manual, 1973). Clostridium rectum and C. cochlearium also appear to be very similar to each other and are the only species in homology group II that produce butyric as the major fermentation acid (Anaerobe Laboratory Manual, 1973).

Homology group III. The six species in homology group III have little or no rRNA nucleotide sequence similarity with the reference strains of groups I and II. All of the species appear to have rather small cells (Anaerobe Laboratory Manual, 1973). The nutritional 
requirements of $C$. ramosum are minimal (Table I) whereas the other species have more complex requirements ( $C$. thermosaccharolyticum was not tested). Clostridium ramosum was used as a reference (Table 3), and none of the other species had any homology with it. There are some similarities between $C$. propionicum and $C$. sticklandii in that they utilize few or no carbohydrates and have similar patterns of fermentation products although they differ in motility (Anaerobe Laboratory Manual, 1973).

High $\%$ GC species. Several strains of $C$. innocuum were included in this study and DNA from all but strain 3794C have high homology with the reference strain (Table 4). Although strain $3794 \mathrm{C}$ had only $4 \mathrm{I} \%$ DNA homology with the reference strain, ATCCI 450 I, conservation of rRNA cistrons is demonstrated by the RNA from strain $3794 \mathrm{C}$ which competed as effectively as homologous RNA (Table 4). The four other species of clostridia that have high $\%$ GC DNA do not have significant rRNA homology with $C$. innocuum. Clostridium sphenoides and $C$. indolis appear to be phenotypically similar (Anaerobe Laboratory Manual, 1973). Several Bacillus species having similar \% GC values have only background levels of rRNA homology with $C$. innocuum (Table 4 ).

The most important question about rRNA homology experiments is how much genetic relatedness is being measured; has the arrangement of nucleotides in rRNA cistrons been conserved independently of other cistrons, or do they just evolve at a slower rate? If rRNA cistrons have been conserved independently of others, there may be little correlation between homology results and the phenotypic characteristics usually used in characterizing species. Similar results would be obtained for traits, such as the lack of an enzyme activity, that may have resulted from a single mutation step. If various segments of the genome evolve independently of others, the taxonomic usefulness of rRNA similarities or of other characteristics would be limited. On the other hand, if rRNA cistrons have evolved at a slower rate than the bulk of the cistrons in an organism's genome, many phenotypic expressions could correlate with rRNA nucleotide sequence similarities. Although the nucleotide sequences of many cistrons may be evolved to such an extent that, for two particular organisms, they cannot be measured by DNA homology, some of the phenotypic characters of the two organisms may remain similar and correlate with the degree of rRNA homology. The rRNA homology studies would then provide a basis for selecting phenotypically conserved characteristics that represent cistrons that are partially conserved. Some of the apparent correlations that we have observed in the genus Clostridium are discussed below.

Cell morphology. Cell shape and size correlates very well with the rRNA homology results in the present study, in that if there is a high level of rRNA homology, cells from these organisms will have very similar morphology (e.g. groups I-A, I-C, I-F and I-H); however, the converse need not be true. Motility also appears to correlate reasonably well with the rRNA homology groups. The position of the spore in the cell has been used as a distinguishing characteristic for identification (Smith \& Hobbs, 1974); however, it correlates very poorly with homology results. The species numbers (Table I) are based in part on spore location (Smith \& Hobbs, 1974), and these numbers are well randomized in Table 3 .

Cell wall structure, notably the type and/or isomeric form of the linking diamino acid and the kinds of cell wall sugars, has been found to correlate with the results of DNA homology studies (Cummins \& Johnson, 197I ; Johnson \& Cummins, 1972). From our limited data, cell wall structure does not appear to correlate with the rRNA similarities. For example, the meso isomer of $\alpha, \epsilon$-diaminopimelic acid (DAP) is found in all of the species tested in homology group I-A, but the cell wall sugars differ between $C$. butyricum and $C$. beijerinckii (Cummins \& Johnson, I97I). Clostridium sordellii in homology group II (Table 3) has meso 
DAP whereas C. tertium, which is also in group II, has no DAP (Cummins \& Johnson, I97I).

Nutritional requirements and substrate utilization. Growth patterns in the two types of media shown in Table I correlate reasonably well with the rRNA homology values, although within some homology groups (e.g. I-A) there is diversity of nutritional requirements. The ability to ferment carbohydrates correlates with rRNA homology results, but the fermentation of particular carbohydrates may not. The species in homology group I are mainly saccharolytic with three exceptions: those in subgroups I-F and I-G are proteolytic and appear to ferment only a few carbohydrates, and those in subgroup I-K are proteolytic only (Anaerobe Laboratory Manual, 1973; Smith \& Hobbs, 1974). Many of the species in group II are proteolytic and the majority utilize few if any carbohydrates (Anaerobe Laboratory Manual, 1973). Gelatin liquefaction does not correlate with rRNA homology results although the digestion of meat and casein does. Gelatin liquefaction can probably be brought about by several enzymes and may not be a very useful taxonomic characteristic.

Mead (1971) suggested that amino acid fermentation patterns may be of taxonomic value. We have found little correlation between the groups established by Mead and our rRNA homology groups. Therefore, we would consider the fermentation of particular amino acids on the same level as the utilization of individual carbohydrates.

Fermentation acids. The kinds of acids that are produced in a peptone-yeast extractglucose medium correlate with the rRNA homology results, in that species that have high homology produce similar acid patterns. As in cell morphology, however, the converse need not be true. For example, the species in each of the subgroups I-A, I-F and I-H have high rRNA homology and a unique pattern of fermentation acids, but C. ghoni, C. sordellii and $C$. bifermentans (homology group II), while having low homology with C. sporogenes (subgroup I-F), produce very similar patterns of fermentation acids. These results suggest that the $23 \mathrm{~S}$ rRNA cistrons are more conserved, since subgroups I-A, I-F and I-H are all more related to each other than are any of them to species in group II. The results also lead to the quandary that the rRNA cistrons may be evolving somewhat independently of other cistrons. However, there is a limited number of compounds that can be produced from carbohydrate and amino acid catabolism. Similar products can result from distinct catabolic pathways or at least very distinct proteins (enzymes) in phenotypically similar pathways. Additional information on the catabolism of these organisms would be very useful in resolving this dilemma.

Although the conservation of rRNA cistrons has been evident in all groups of organisms that have been studied, detailed investigations of bacterial groups have been limited. The notable exception to this is the work of Palleroni et al. (1973) on the genus Pseudomonas. Five species groups were delineated within the genus on the basis of rRNA homology experiments. The intra- and interhomologies of the Pseudomonas groups are similar to those that we have found among the species in the genus Clostridium. Although arbitrary cut-off levels of homology have been used in defining the homology groups, the correlations of phenotypic traits with the groups suggest that rRNA homology results can be used as an index of general relatedness and will provide a sound base on which to construct taxonomic or possibly identification schemes.

We are indebted for technical assistance to Habiba Najafi. Discussions of the manuscript with C. S. Cummins, L. DS. Smith, L. V. Holdeman and W. E. C. Moore were greatly appreciated. This work was supported by Public Health Service Grant GM 14604 from the National Institute of General Medical Sciences. 


\section{REFERENCES}

Anaerobe Laboratory Manual (1973). Edited by L. V. Holdeman and W. E. C. Moore. Blacksburg, Virginia: Virginia Polytechnic Institute and State University.

ANDerson, R. S. \& Ordal, E. J. (I972). Deoxyribonucleic acid relationships among marine vibrios. Journal of Bacteriology 109, 696-706.

Bendich, A. J. \& MCCARTHY, B. J. (1970). Ribosomal RNA homologies among distantly related organisms. Proceedings of the National Academy of Sciences of the United States of America 65, 349-356.

Bicknell, J. N. \& Douglas, H. C. (1970). Nucleic acid homologies among species of Saccharomyces. Journal of Bacteriology ror, 505-5I 2.

Cummins, C. S. \& Johnson, J. L. (I97I ). Taxonomy of the clostridia: wall composition and DNA homologies in Clostridium butyricum and other butyric acid-producing clostridia. Journal of General Microbiology 67, 33-46.

DenhardT, D. T. (1966). A membrane-filter technique for the detection of complementary DNA. Biochemical and Biophysical Research Communications 5, 64I-646.

Dor, R. H. \& Igarashi, R. T. (I965). Conservation of ribosomal and messenger ribonucleic acid cistrons in Bacillus species. Journal of Bacteriology 90, 384-390.

Dubnau, D., Smith, I., Morell, P. \& Marmur, J. (1965). Gene conservation in Bacillus species. I. Conserved genetic and nucleic acid sequence homologies. Proceedings of the National Academy of Sciences of the United States of America 54, 49I-498.

Eklund, M. W. \& Poysky, F. T. (1974). Interconversion of type C and D strains of Clostridium botulinum by specific bacteriophages. Applied Microbiology 27, 25 I-258.

Eklund, M. W., Poysky, F. T. \& ReEd, S. M. (1972). Bacteriophage and the toxigenicity of Clostridium botulinum type D. Nature New Biology 235, I6-I 7 .

Eklund, M. W., Poysky, F. T., Reed, S. M. \& Smith, C. A. (1971). Bacteriophage and the toxigenicity of Clostridium botulinum type C. Science, New York 172, 480-482.

Gibson, I. (1967). RNA homologies between protozoa. Journal of Protozoology 14, 690-697.

Giles, K. W. \& Myers A. (1965). An improved method for the estimation of deoxyribonucleic acid. Nature, London 206, 93.

Gillespie, D. \& SPIEgelman, S. (I g65). A quantitative assay for DNA-RNA hybrids with DNA immobilized on a membrane. Journal of Molecular Biology 12, 829-842.

InOUE, K. \& IIDA, H. (I 970). Conversion of toxigenicity in Clostridium botulinum type C. Japanese Journal of Microbiology 14, 87-89.

Johnson, J. L., Anderson, R. S. \& Ordal, E. J. (1970). Nucleic acid homologies among oxidase-negative Moraxella species. Journal of Bacteriology ror, 568-573.

Johnson, J. L. \& Cummins, C. S. ( I972). Cell wall composition and deoxyribonucleic acid similarities among the anaerobic coryneforms, classical propionibacteria, and strains of Arachnia propionica. Journal of Bacteriology 109, 1047-1066.

Johnson, J. L. \& Ordal, E. J. (1968). Deoxyribonucleic acid homology in bacterial taxonomy: effect of incubation temperature on reaction specificity. Journal of Bacteriology 95, 893-900.

KIRBY, K. S. (I 967). Isolation of nucleic acids with phenolic solvents, pp. 87-99. In Methods in Enzymology, vol. 12B. New York: Academic Press.

LAIRD, C. D. \& MCCARTHY, B. J. (I968). Magnitude of interspecific nucleotide sequence variability in Drosophila. Genetics 60, 303-322.

LeE, W. H. \& RiemanN, H. (1970a). Correlation of toxic and non-toxic strains of Clostridium botulinum by DNA composition and homology. Journal of General Microbiology 6o, I $17-123$.

LeE, W. H. \& RiemanN, H. (1970 $b$ ). The genetic relatedness of proteolytic Clostridium botulinum strains. Journal of General Microbiology 64, 85-90.

Marmur, J. (1961). A procedure for the isolation of DNA from microorganisms. Journal of Molecular Biology 3, 208-218.

MARmur, J. \& Doty, P. (I962). Determination of the base composition of deoxyribonucleic acid from its thermal denaturation temperature. Journal of Molecular Biology 5, 109-1 8.

MCCARThy, B. J. (I967). Arrangement of base sequences in deoxyribonucleic acid. Bacteriological Reviews 3r, $215^{-229 .}$

MEAD, G. C. (1971). The amino acid-fermenting clostridia. Journal of General Microbiology 67, 47-56.

Moore, W. E. C., Cato, E. P. \& Holdeman, L. V. (1966). Fermentation patterns of some Clostridium species. International Journal of Systematic Bacteriology 16, 383-4I 5 . 
Moore, R. L. \& MCCARThy, B. J. (1967). Comparative study of ribosomal ribonucleic acid cistrons in enterobacteria and myxobacteria. Journal of Bacteriology 94, 1066-1074.

NiYOGI, S. K. (I969). The influence of chain length and base composition on the specific association of oligoribonucleotides with denatured deoxyribonucleic acid. Journal of Biological Chemistry 244, 1576$158 \mathrm{I}$.

Pace, B. \& Campbell, L. L. ( 197 I $a$ ). Homology of ribosomal ribonucleic acid of Desulfovibrio species with Desulfovibrio vulgaris. Journal of Bacteriology ro6, 717-719.

PACE, B. \& CAMPBell, L. L. (I97I $b$ ). Homology of ribosomal ribonucleic acid of diverse bacterial species with Escherichia coli and Bacillus stearothermophilus. Journal of Bacteriology 107, 543-547.

Palleroni, N. J., Kunisawa, R., Contopoulou, R. \& Doudoroff, M. (1973). Nucleic acid homologies in the genus Pseudomonas. International Journal of Systematic Bacteriology 23, 333-339.

Pigott, G. H. \& CARr, N. G. (I 972). Homology between nucleic acids of blue-green algae and chloroplasts of Euglena gracilis. Science, New York 175, 1259-126I.

Pittman, K. A. \& Bryant, M. P. (1964). Peptides and other nitrogen sources for growth of Bacteroides ruminicola. Journal of Bacteriology 88, 40I-4IO.

Smith, L. DS. \& Hoвbs, G. (1974). Genus III. Clostridium Prazmowski I88o, 23. In Bergey's Manual of Determinative Bacteriology, 8th edn, pp. 55I-572. Edited by R. E. Buchanan and N. E. Gibbons. Baltimore: The Williams and Wilkins Co.

Stadtman, E. R., Stadtman, T. C., Pastan, I. \& Smith, L. DS. (I972). Clostridium barkeri sp. n. Journal of Bacteriology II0, 758-760.

Takahashi, H., SaIto, H. \& IKedA, Y. (1967). Species specificity of the ribosomal RNA cistrons in bacteria. Biochimica et biophysica acta $\mathbf{1 3 4}, 124-\mathrm{I} 33$.

Tonomura, B., Malkin, R. \& Rabinowitz, J. C. (I965). Deoxyribonucleic acid base composition of clostridial species. Journal of Bacteriology 89, I 438-I 439.

Vodkin, M. \& Katterman, F. R. H. (I97I). Divergence of ribosomal RNA sequences within Angiospermae. Genetics 69, 435-45I.

Wu, J. I. J., RiemanN, H. \& LeE, W. H. (1972). Thermal stability of the deoxyribonucleic acid hybrids between the proteolytic strains of Clostridium botulinum and Clostridium sporogenes. Canadian Journal of Microbiology 18, 97-99. 